\title{
Evaluasi produk berlabel standar: Persepsi konsumen pria dan wanita
}

\author{
Medi Yarmen ${ }^{1}$, I Gede Mahatma Yudha Bakti² \\ 1,2 (LIPI) Lembaga Ilmu Pengetahuan Indonesia, Jakarta \\ E-mail: gede_tok@yahoo.co.id
}

\begin{abstract}
Standard label is one of product labels is often used by manufacture to market a product. This is important for manufacture because a standard label has a close relationship with level of product quality. Moreover, consumers sometimes have difficulty in evaluating product quality. Consequently, they often consider informations that contained in the product or package, including consider the presence of standard label. Consumers' gender is one of the factors that determine how consumers use the standard label in the decision to buy a product. Unfortunately, studies that tested empirically related to the role of gender in purchasing decisions of labeled-standard product is very rarely. This study aims to understand whether male and female consumer have different consideration in evaluating products labeled standard. This research was conducted by questionnaire survey method. Data collection was conducted by convenience sampling technique. Total of 207 respondents were ready to participate in this study. This research was conducted on two aspects, namely (1) the level of brand familiarity, and (2) the level of product involvement. Various products were tested, such as calculator, detergent, laptop, smartphone, flashlight, and electric fan The results of this study found that in general male and female have the similiar opinion in evaluating product labeled standard. Even so, the results of this study also showed that under certain conditions, male and female may have different perception in evaluating products labeled standard.
\end{abstract}

Keywords: gender, standard label, product quality, willingness to buy, brand familiarity, product involvment

\begin{abstract}
Abstrak
Label standar adalah salah satu label produk yang sering dipakai oleh produsen untuk memasarkan suatu produk. Hal tersebut penting bagi perusahaan karena label standar memiliki hubungan yang erat dengan kualitas produk. Apalagi, kadang kala konsumen mengalami kesulitan dalam mengevaluasi kualitas suatu produk. Akibatnya, mereka sering mempertimbangkan informasi-informasi yang tertera pada suatu produk atau kemasannya, termasuk mempertimbangkan kehadiran label standar. Jenis kelamin konsumen merupakan salah satu faktor yang menentukan bagaimana konsumen menggunakan label standar dalam keputusannya membeli suatu produk. Sayangnya, penelitian yang menguji secara empiris terkait dengan peran jenis kelamin dalam keputusan pembelian produk berlabel standar masih sangat jarang dilakukan. Penelitian ini bertujuan untuk mengetahui apakah konsumen pria dan wanita memiliki perbedaan pertimbangan dalam mengevaluasi produk berlabel standar. Penelitian ini dilakukan dengan cara teknik survei dengan kuesioner. Pengambilan data dilakukan dengan cara teknik convenience sampling. Sebanyak 207 responden bersedia untuk berpartisipasi dalam penelitian ini. Pada penelitian ini pengujian dilakukan pada dua aspek, yaitu (1) level pengenalan merek, dan (2) level keterlibatan produk. Berbagai produk yang diuji antara lain kalkulator, deterjen, laptop, smartphone, senter, dan kipas angin. Hasil penelitian ini menemukan bahwa secara umum pria dan wanita memiliki kesamaan pandangan dalam mengevaluasi produk berlabel standar. Meskipun begitu, hasil penelitian ini juga menunjukan bahwa dalam kondisi tertentu, pria dan wanita dapat memiliki perbedaan persepsi dalam mengevaluasi produk berlabel standar.
\end{abstract}

Kata kunci: jenis kelamin, label standar, kualitas produk, keinginan untuk membeli, pengenalan merek, keterlibatan produk

JEL: M30, M31, M39

DOI: 10.20885/jsb.vol21.iss1.art4

\section{Pendahuluan}

Salah satu unsur penting dan tidak boleh diabaikan oleh setiap produsen dalam mempromosikan produknya adalah label produk (Kotler dan Keller, 2012). Hal ini dikarenakan label produk berperan 
penting dalam memberikan informasi kepada konsumen dan membantu mereka secara langsung dalam mengevaluasi dan memutuskan produk apa yang ingin dibelinya (Dimara dan Skuras, 2005). Secara umum, label produk dapat diartikan sebagai tanda yang terpasang secara sederhana atau gambar yang dirancang secara rumit yang merupakan bagian dari bungkus produk (Kotler dan Keller, 2012). Dengan demikian, label produk dapat berupa angka, huruf, tulisan, gambar, simbol atau kombinasinya yang menginformasikan sesuatu mengenai suatu produk.

Salah satu jenis label produk yang penting untuk dipertimbangkan oleh setiap produsen adalah label standar. Beberapa contoh label standar yang sering ada pada produk di Indonesia, antara lain label SNI, HACCP, ISO, dan lainnya. Pentingnya produsen mempertimbangkan penggunaan label standar karena label standar memiliki hubungan yang erat dengan kualitas produk. Bahkan, banyak konsumen menganggap bahwa produk berlabel standar termasuk kategori produk yang berkualitas. Beberapa peneliti telah menyatakan bahwa pemberian label standar pada suatu produk dapat mempengaruhi secara positif terhadap keputusan konsumen dalam membeli suatu produk (Walley, Han, Albaum, dan Thirkel,1999; Fotopoulos dan Krystallis, 2003). Lebih spesifik, Resano, Sanjuan, dan Albisu, (2007) dan Carpenter dan Larcenaux (2008) juga menyatakan bahwa kehadiran label standar memungkinkan konsumen untuk menyimpulkan bahwa produk berlabel standar adalah produk yang berkualitas (Verbeke, Pieniak, Guerrero, dan Hersleth, 2012).

Berkaitan dengan pernyataan tersebut, beberapa peneliti lain juga menambahkan bahwa faktor demografi berperan penting dalam menentukan bagaimana konsumen menggunakan label standar dalam keputusannya membeli suatu produk. Salah satu faktor demografi yang mempengaruhi konsumen dalam keputusan pembelian produk adalah faktor jenis kelamin. Berbagai peneliti telah menyatakan bahwa jenis kelamin pria dan wanita mempunyai cara yang berbeda dalam mengevaluasi suatu produk (Guthrie, Jonathan, Fox, Cleveland, dan Welsh, 1995; Nayga, 1996; 2000; Drichoutis, Lazaridis, dan Nayga, 2006; Rahmawati, 2016). Meskipun begitu, untuk konteks di Indonesia, sejauh ini penulis memandang bahwa belum ada penelitian yang menguji empiris terkait dengan perbedaan jenis kelamin dalam mengevaluasi produk berlabel standar. Apalagi, sampai saat ini juga belum ada penelitian yang komperhensif menguji perbedaan jenis kelamin dalam mengevaluasi produk berlabel standar dengan melihat konteks pengenalan merek (brand familiarity) dan keterlibatan produk (product involvement). Atas dasar kondisi tersebut, penulis memandang perlu dilakukan sebuah penelitian mengenai peran jenis kelamin dalam mengevaluasi produk berlabel standar. Selain itu, hasil penelitian ini juga dapat memberikan kontribusi keiilmuan, khususnya di bidang ilmu pemasaran dan perilaku konsumen.

Penelitian ini bertujuan untuk mengetahui ada atau tidak ada perbedaan antara konsumen pria dan wanita dalam mengevaluasi produk berlabel standar. Dalam proses evaluasi tersebut, terdapat dua aspek yang diteliti, yaitu kualitas produk (product quality) dan keinginan untuk membeli (willingness to buy). Dengan demikian, pertanyaan penelitian ini adalah apakah konsumen pria dan wanita memiliki perbedaan persepsi terhadap kualitas produk dan keinginan untuk membeli produk berlabel standar.

Selanjutnya, label standar yang diuji dalam penelitian ini adalah label standar ISO 9001. Terdapat beberapa alasan penulis menggunakan label ISO 9001. Pertama, label 9001 adalah label standar internasional sistem manajemen kualitas yang dapat diimplementasikan di semua jenis produk, baik itu dalam bentuk barang atau pelayanan, sehingga penelitian ini dapat berkontribusi secara luas (ISO, 2015). Kedua, ISO 9001 merupakan standar internasional yang paling populer di dunia, karena standar tersebut banyak diadopsi oleh berbagai perusahaan, berbagai produk, dan berbagai negara (lihat www.iso.org). Dengan demikian, penulis menganggap label ISO 9001 merupakan label yang cukup dikenal dimata konsumen (Tannock dan Brown, 2006). Ketiga, ISO 9001 merupakan standar manajemen kualitas yang implementasinya bersifat sukarela (Sampaio, Saraiva, dan Rodrigues, 2009), sehingga setiap perusahaan bebas untuk mengadopsi ISO 9001 atau tidak. 


\section{Tunjauan Pustaka dan Hipotesis}

\section{Label Standar}

Setiap produk pasti memiliki label, karena label produk adalah segala sesuatu yang terpasang pada produk atau kemasannya yang memuat angka, huruf, tulisan, gambar, simbol, atau kombinasinya yang bertujuan untuk menginformasikan sesuatu mengenai suatu produk (Kotler dan Keller, 2012). Dengan kata lain, apapun yang menempel pada produk atau kemasannya dapat dikatakan sebagai bagian dari label produk. Lebih lanjut, secara umun, kegunaan dari label produk adalah (1) untuk mengidentifikasi produk dan merek; (2) untuk menggambarkan sesuatu dari produk, seperti dimana dibuat, kapan dibuat, bagaimana penggunaannya, dan lainnya; serta (3) untuk mempromosikan merek produk, dimana dapat meningkatkan hubungan dengan pelanggan.

Salah satu jenis label yang ada pada suatu produk adalah label standar. Label tersebut merupakan bagian dari atribut ekstrinsik dari suatu produk (Caswell, 2006). Lebih lanjut, label standar sering juga disebut dengan label kualitas. Berbagai literatur telah menyebutkan bahwa label standar dapat dibedakan jenisnya berdasarkan kiriteria tertentu. Berdasarkan kriteria sifatnya, label standar dapat dibedakan menjadi dua jenis, yaitu label standar wajib (obligatory) dan sukarela (voluntary) (Velčovska dan Sadílek, 2014). Label standar wajib adalah label standar yang memang wajib diterapkan oleh semua produsen. Hal ini dikarenakan adanya peraturan yang sudah ditetapkan oleh pemerintah. Sedangkan, label standar sukarela adalah label standar yang implementasinya bersifat sukarela bagi setiap perusahaan. Dengan kata lain, setiap perusahaan bebas untuk mengadopsi standar tersebut atau tidak. Para perusahaan mengadopsi label standar sukarela, karena perusahaan meyakini dengan mengadopsi standar tersebut akan memberikan keunggulan kompetitif bagi produk dan perusahaannya (Velcovska dan Sadílek, 2014).

Selanjutnya, label standar juga dapat dikelompokan berdasarkan kriteria wilayah, yaitu label standar nasional, regional, dan internasional (Velcovska dan Sadílek, 2014). Contohnya, (1) label standar internasional adalah label ISO (International Standard for Organization); (2) label standar regional untuk Europan Union (EU) adalah PDO (Protected Designation of Origin), PGI (Protected Geographical Indication), TSG (Traditional Speciality Guaranted); dan (3) label standar nasional untuk Indonesia adalah SNI (Standar Nasional Indonesia), untuk Australia adalah Australian Strandard, untuk Jepang adalah JIS (Japanese Industrial Standard), dll.

Secara konseptual label standar didefinisikan sebagai tanda yang ada pada produk atau kemasannya yang menunjukan bahwa produk atau proses pembuatannya telah sesuai dengan standar tertentu dan kepatuhannya telah disertifikasi oleh pihak ketiga (Velčovska dan Marhounova, 2005; Velčovska dan Sadílek, 2014). Adapun, van Dam dan van Trijp (2006) menyebutkan bahwa label standar adalah informasi pada produk yang menggambarkan kualitas obyektif dan menunjukan bahwa produk telah memenuhi kriteria tertentu atau skema sertifikasi. Dengan demikian, label standar dapat didefinisikan sebagai informasi yang menyatakan bahwa produk tersebut atau proses pembuatan produk tersebut telah memenuhi standar tertentu yang menunjukan tingkat kualitas obyektif.

\section{Hipotesis}

Secara umum, konsumen dapat dikelompokan menjadi dua kategori, yaitu konsumen berjenis kelamin pria dan wanita (Kotler dan Keller, 2012). Pengelompokan konsumen tersebut dibagi berdasarkan sifat fisik/biologis atau psikologisnya. Literatur perilaku konsumen telah menyatakan bahwa pria dan wanita memiliki cukup banyak perbedaan sifat dan karakteristik yang membuat mereka beda dalam berperilaku (Solomon, 2013). Akibatnya, perbedaan fisik dan psikologis mereka melahirkan perbedaan kebutuhan, harapan, keinginan, gaya hidup, lingkungan sosial, dan pola konsumsi (Rakhmawati, 2016). 
Teori yang menjelaskan perbedaan jenis kelamin dalan perilaku konsumen adalah teori skema gender. Teori tersebut diperkenalkan oleh Bem (1981) bahwa seseorang akan menunjukkan ciri-ciri, sikap, dan perilaku secara konsisten dengan identitas jenis kelamin mereka. Dalam konteks perilaku konsumen, teori tersebut menjelaskan bahwa dalam proses pembelian produk, konsumen dapat bertindak sesuai dengan jenis kelaminnya. Sebagai contoh, seseorang wanita cenderung memilih produk yang dapat menggambarkan sifat feminim, dan seseorang pria lebih suka menggunakan produk yang dapat menunjukan sifat kejantanan atau maskulin. Dengan demikian, identitas jenis kelamin seseorang dapat digunakan untuk memprediksi konstruk jenis kelamin yang lebih luas seperti peran, sikap, dan perilaku seseorang.

Penelitian terhadap perbedaan jenis kelamin dalam mengevaluasi suatu produk telah dipelajari sebelumnya oleh beberapa peneliti. Beberapa peneliti seperti Huertas-Leyva, Quattelbaum, Solaz, J. dan Schmitt (2011), Mokhlis (2012), Lumb dan Lall (2013) menyatakan bahwa pria dan wanita memiliki perbedaan persepsi terhadap aspek kualitas produk/pelayanan. Perbedaan tersebut juga dapat terjadi pada aspek keinginan mereka dalam membeli produk (Bae dan Lee, 2011; Wee, Ariff, Zakuan, Tajudin, 2014; Lassen et al., 2016).

Dalam konteks pelabelan produk, beberapa peneliti telah menguji perbedaan jenis kelamin dalam menggunakan label produk sebagai bahan pertimbangan mereka dalam membeli suatu produk (Guthrie, Jonathan, Fox, Cleveland, dan Welsh, 1995; Nayga, 1996; 1999). Hasilnya menyatakan bahwa perempuan lebih memiliki pengetahuan yang lebih terhadap penggunaan label produk (Guthrie, Jonathan, Fox, Cleveland, dan Welsh, 1995). Nayga (1996; 1999) juga memeroleh temuan yang serupa bahwa wanita lebih selektif dalam memperhatikan label produk dari pada pria. Adapun, kajian literatur yang dikerjakan oleh Drichoutis, Lazaridis, dan Nayga (2006) menyatakan bahwa salah satu faktor penentu seseorang mempertimbangkan label standar sebagai bahan evaluasi produk adalah jenis kelamin. Dengan demikian, dapat dikatakan bahwa pria dan wanita memiliki perbedaan pandangan dalam mengevaluasi produk berlabel standar. Atas penjelasan tersebut, hipotesis penelitian ini adalah

H1: Jenis kelamin pria dan wanita memiliki perbedaan persepsi dalam mengevaluasi produk standar, baik pada (a) kualitas produk, dan (b) keinginan untuk membeli produk berlabel standar

\section{Metodologi}

\section{Desain Penelitian}

Desain penelitian ini adalah penelitian kuantitatif. Lebih lanjut, desain pengambilan data dilakukan dengan cara teknik survei dengan kuesioner. Dalam penelitian ini kuesioner dibuat dalam bentuk self-administred questionare, yaitu setiap responden menjawab dan mengisi jawaban sendiri dari beberapa pertanyaan yang diajukan dalam kuesioner (Zikmund, Babin, Carr, dan Griffin, 2008).

Agar hasil penelitian ini dapat memberikan kontribusi penelitian ini secara luas. Hipotesis penelitian ini akan diuji pada 2 studi dengan konteks yang berbeda, yaitu pengenalan merek (brand familiarity) dan keterlibatan produk (product involvement). Alasan penulis menguji pada dua konteks tersebut karena konsumen memiliki keputusan yang berbeda dalam mengevaluasi produk antara merek yang dikenal dan tidak dikenal, atau keterlibatan produk yang tinggi dan rendah (Solomon, 2013).

Studi 1 menguji hipotesis pada konteks level pengenalan merek. Level pengenalan merek produk adalah tingkat pengetahuan konsumen terhadap suatu merek produk. Pada studi 1 hipotesis penelitian ini diuji pada merek yang dikenal (familiar brand) dan merek yang tidak dikenal (unfamiliar brand). Produk yang diuji pada studi 1, adalah detergen bubuk dan kalkulator. Peneliti menguji dua produk tersebut untuk pengembangan penelitian sebelumnya, yaitu Leclerc, Schmitt, dan Dube (1994). Mengingat keterbatasan penelitian ini, penulis tidak bisa menguji semua merek produk detergen bubuk dan kalkulator. Oleh karena itu, penelitian ini hanya menggunakan salah satu merek yang dikenal (familiar brand) dan merek yang tidak dikenal (unfamiliar brand) untuk 
masing-masing produk. Berdasarkan hasil studi pendahuluan (pilot test), penulis mendapatkan bahwa merek kalkulator yang paling dikenal responden adalah Casio dan merek yang paling tidak dikenal adalah Porpo. Sedangkan, pada merek detergen bubuk yang paling dikenal responden adalah Risno dan tidak dikenal adalah Persil. Dengan demikian, pada studi 1 terdapat empat merek yang diuji pada penelitian ini, yaitu Casio, Porpo, Risno, dan Persil.

Disisi lain, studi 2 menguji hipotesis pada konteks level keterlibatan produk. Level keterlibatan produk menunjukan seberapa besar konsumen terlibat dalam mengevaluasi produk. Menurut Solomon (2013) perbadaan tingkat keterlibatan produk dapat mempengaruhi konsumen dalam mengevaluasi produk. Ini artinya keterlibatan produk tinggi dengan keterlibatan produk rendah memiliki penilaian yang berbeda dalam mengevaluasi produk. Pada studi 2 hipotesis penelitian ini diuji pada konteks produk dengan keteribatan tinggi (high involvement) dan keterilibatan rendah (low involvement). Jenis produk yang diuji pada studi 2 adalah produk-produk elektronik karena beberapa alasan, yaitu (1) produk elektronik memiliki berbagai macam produk dengan keterlibatan rendah sampai dengan tinggi, (2) produk elektronik termasuk produk yang sering digunakan manusia untuk menunjang berbagai aktivitas, (3) produk elektronik juga telah banyak dijadikan objek penelitian sebelumnya (lihat Srivastava dan Mitra, 1998; Chao, 2001; Delafrooz dan Goli, 2015; Marakanon dan Panjakajornsak, 2017). Adapun, produk elektronik yang dipilih pada studi 2 adalah laptop, smartphone, senter dan kipas angin. Empat produk tersebut dipilih berdasarkan hasil studi pendahuluan yang dilakukan oleh penulis bahwa (1) laptop dan smartphone merupakan produk dengan keterlibatan paling tinggi, serta (2) senter dan kipas angin merupakan produk dengan keterlibatan paling rendah.

\section{Unit Analisis}

Agar hasil penelitian ini memberikah hasil yang spesifik dan terfokus, penulis mencoba membatasi penelitian ini hanya pada kalangan remaja. Atas dasar pertimbangan tersebut, unit analisis penelitian ini adalah konsumen dengan umur berkisar 17 - 25 tahun. Lebih lanjut, pengumpulan data penelitian ini dilakukan dengan teknik convenience sampling. Dalam penelitian prilaku konsumen, teknik tersebut masih layak dan pantas digunakan untuk mempelajari perilaku seseorang (Park dan Sullivan, 2009; Bakti dan Sumaedi, 2013; Yarmen et al., 2016). Berkaitan dengan hal tersebut, kuesioner penelitian ini disebar kepada mahasiswa S1 yang berusia antara 17-25 tahun. Hal ini dikarenakan penggunaan mahasiswa sebagai objek penelitian sering digunakan dibidang marketing (Wiley, Han, Albaum, dan Thirkell, 2009).

Tabel 1. Demografi responden penelitian

\begin{tabular}{llc}
\hline \multicolumn{1}{c}{ Aspek } & \multicolumn{1}{c}{ Kategori } & Persentase (\%) \\
\hline Universitas & Universitas Indonesia & 34,8 \\
& Universitas Jendral Soedirman & 64,7 \\
Jenis Kelamin & Pria & 43,0 \\
\multirow{3}{*}{ Umur } & Wanita & 57,0 \\
& $17-19$ tahun & 45,0 \\
\multirow{5}{*}{ Tingkat pekuliahan } & $20-22$ tahun & 50.7 \\
& $23-25$ tahun & 2,4 \\
& Tingkat I (Semester 1 - Semester 2) & 19,3 \\
& Tingkat II (Semester 3 - Semester 4) & 27,5 \\
& 2Tingkat III (Semester z5) & 53,1 \\
\hline
\end{tabular}

Mengingat tidak adanya data pasti mengenai jumlah populasi mahasiswa berumur $17-25$ di Indonesia. Maka jumlah minimal sampel penelitian ini dihitung dengan rumus Lemeshow. Bila penulis menyakini bahwa nilai $Z=1,96 ; p$ (maximal estimation) $=0,5$; dan alpha $=10 \%$, maka jumlah minimum sampel yang harus diambil adalah sebanyak 96 responden. Pada penelitian ini, 
penulis telah mendapatkan 207 mahasiswa yang berasal dari Universitas Indonesia dan Universitas Jendral Soedirman. Dengan demikian, jumlah responden penelitian ini telah memenuhi persyaratan jumlah sampel minimum untuk mewakili populasi. Lebih lanjut, 207 responden tersebut terdiri dari mahasiswa berjenis kelamin pria sebanyak 43 persen dan wanita sebanyak 57 persen. Adapun, mayoritas mahasiswa tersebut berumur antara 20 - 22 tahun dengan rata-rata berumur 19,6. Sedangkan, pada aspek tingkat perkuliahan paling banyak mahasiswa penelitian ini masih berada pada tingkat ketiga keatas (semester $\geq 5$ ). Gambaran demografis responden penelitian ini dapat dilihat pada tabel 1 .

\section{Variabel}

Berkaitan dengan tujuan penelitian ini, terdapat dua variabel yang harus diukur oleh penulis, yaitu persepsi kualitas produk berlabel standar dan keinginan untuk membeli produk berlabel standar. Mengingat dua variabel penelitian ini merupakan variabel yang tidak bisa diukur secara langsung, maka dalam pengukurannya diperlukan beberapa indikator pengukuran (Diamantopoulos, Sarstedt, Fuchs, Wilczynski, dan Kaiser, 2012).

Tabel 2. Operasionalisasi pengukuran variabel persepsi kualitas produk dan keinginan untuk membeli produk berlabel standar

\begin{tabular}{lll}
\hline \multicolumn{1}{c}{ Variabel } & \multicolumn{1}{c}{ Item Indikator Pengukuran } & \multicolumn{1}{c}{ Sumber } \\
\hline $\begin{array}{l}\text { Kualitas produk berlabel } \\
\text { standar }\end{array}$ & $\begin{array}{l}\text { KP1: Kesan terhadap produk } \\
\text { KP2: Kualitas produk }\end{array}$ & Srivastava dan Mitra (1998) \\
& KP3: Kinerja produk & \\
Keinginan untuk & NB1: Kemungkinan membeli produk & Zhang dan Zinkhan (2006) \\
membeli produk & NB2: Probabilitas (peluang) membeli produk & \\
berlabel standar & NB3: Kemustahilan membeli produk & \\
\hline
\end{tabular}

Pada penelitian ini definisi operasional dari persepsi kualitas produk berlabel standar adalah persepsi mahasiswa terhadap tingkat kinerja produk berlabel standar produk (Mitra dan Golder, 2006). Sedangkan, keinginan untuk membeli produk berlabel standar dioperasionalisasikan sebagai keinginan mahasiswa untuk membeli produk berlabel standar (Zhang dan Zinkhan, 2006). Berkaitan dengan definisi operasional tersebut, indikator pengukuran persepsi kualitas produk berlabel standar diukur menggunakan tiga item yang mengadopsi penelitian Srivastava dan Mitra (1998). Di sisi lain, indikator pengukuran keinginan untuk membeli produk berlabel standar juga menggunakan tiga item yang mangacu pada penelitian Zhang dan Zinkhan (2006). Rincian indikator pengukuran variabel persepsi kualitas produk dan keinginan untuk membeli produk berlabel standar dapat dilihat pada tabel 2.

\section{Pengambilan Data}

Pada penelitian ini pengambilan data dilakukan berdasarkan kriteria dan jumlah unit analisis yang sudah ditetapkan sebelumnya. Pengambilan data dilakukan dengan penyebaran kuesioner dan meminta setiap responden untuk memberikan persepsinya terhadap beberapa iklan cetak yang diberikan oleh penulis. Sebelum responden memberikan jawabannya, mereka diminta untuk melihat terlebih dahulu beberapa iklan cetak yang diberikan oleh peneliti. Adapun, iklan cetak pada penelitian ini berfungsi sebagai bahan evaluasi yang harus dinilai oleh setiap responden. Pada penelitian ini, iklan cetak yang dilihat responden terdiri dari gambar, nama merek, label standar, dan kalimat promosi (Torres dan Briggs, 2007). Dalam pengembilan data, penulis mendatangi Universitas Indonesia dan Universitas Jendral Soedirman untuk mencari unit analisis yang sudah ditetapkan sebelumnya. Setelah itu, pengambilan data dilakukan di dalam kelas. Tujuannya adalah untuk mengurangi faktor-faktor lain yang tidak dapat dikendalikan oleh penulis dan faktor-faktor 
tersebut mungkin dapat mempengaruhi responden dalam memberikan persepsinya. Adapun, pengambilan data untuk Studi 1 penelitian ini dilakukan pada mahasiswa Universitas Indonesia dan Studi 2 dilakukan pada Universitas Jenderal Soedirman. Mengingat konteks yang diteliti antara mahasiswa Universitas Indonesia dan Universitas Jenderal Soedirman berbeda maka tidak dapat dilakukan uji t-test antara dua universitas tersebut.

\section{Analisis}

Pada penelitian ini uji validitas kuesioner dilakukan dengan analisis faktor (Hair, Anderson, Tatham, dan Black, 2006). Uji validitas bertujuan untuk mencari tahu apakah alat ukur yang digunakan benar-benar mengukur apa ingin diteliti (Cooper dan Schindler, 2011). Secara statistik, kuesioner telah memenui kriteria validitas yang baik, ketika hasil analisis faktor menemukan (1) nilai KaiserMeyer-Olkin (KMO) berada diantara 0,5 - 1 dengan nilai signifikansi lebih kecil dari nilai alpha (5 persen); (2) nilai measures of sampling adequacy (MSA) diatas 0,5 ; dan (3) nilai faktor loading diatas atas 0,5 untuk masing-masing indikator pengukuran.

Disisi lain, uji reliabilitas kuesioner penelitian ini dianalisis dengan cronbach alpha. Uji reliabilitas dilakukan dengan tujuan untuk mengetahui tingkat konsistensi kuesioner sebagai instrumen pengukuran (Hair, Anderson, Tatham, dan Black, 2006). Secara statistik, instrumen pengukuran dikatakan telah reliabel ketika nilai conbach alpha lebih besar dari 0,7. Adapun, untuk uji hipotesis penelitian ini, penulis menggunakan teknik analisis independen sample t-test. Analisis independen sample t-test merupakan teknik analisis statistik untuk mengetahui ada tidaknya perbedaan dua kelompok yang saling independen secara signifikan. Hasil analisis independen sample t-test menunjukan adanya perbedaan kelompok secara signifikan ketika nilai signifikansi yang diperoleh lebih kecil dari nilai alpha (Hair, Anderson, Tatham, dan Black, 2006).

\section{Hasil dan Pembahasan}

\section{Uji Validitas Kuesioner}

Secara umum, uji validitas dilakukan untuk mengetahui apakah alat ukur yang digunakan benarbenar mengukur apa ingin diteliti (Cooper dan Schindler, 2011). Pada konteks penelitian ini, kuesioner dikatakan valid ketika indikator pengukuran yang digunakan memang dapat mengukur persepsi kualitas produk dan keinginan untuk membeli produk berlabel standar. Hasil uji validitas instrumen penelitian ini dapat dilihat pada tabel 3. Dari tabel tersebut dapat dinyatakan bahwa instrumen telah memenuhi kriteria validitas yang baik. Pada pengukuran variabel persepsi kualitas produk dan keinginan untuk membeli produk, hasilnya menemukan bahwa (1) nilai KMO setiap variabel masih diatas 0,5 dan nilai signifikansi lebih kecil dari nilai aplha 5 persen., dan (2) nilai MSA dan faktor loading setiap indikator juga masih diatas 0,5.

Tabel 3. Uji Validitas Kuesioner

\begin{tabular}{lcccc}
\hline \multicolumn{1}{c}{ Variabel } & Indikator & KMO (Sig.) & MSA & Nilai Loading \\
\hline Kualitas produk & KP1 & $0,720(0,000)$ & 0,807 & 0,887 \\
berlabel standar & KP2 & & 0,659 & 0,946 \\
& KP3 & & 0,722 & 0,916 \\
Keinginan untuk membeli produk & NB1 & $0,695(0,000)$ & 0,667 & 0,928 \\
berlabel standar & NB2 & & 0,633 & 0,950 \\
& NB3 & & 0,855 & 0,858 \\
\hline
\end{tabular}

\section{Uji Reliabilitas Kuesioner}

Uji reliabilitas bertujuan untuk mengetahui apakah alat ukur yang digunakan benar-benar memberikan hasil pengukuran yang konsisten (handal). Pada konteks penelitian ini, kuesioner 
disebut reliabel ketika indikator pengukuran yang digunakan dapat memberikan hasil pengukuran yang konsisten (handal), baik untuk variabel persepsi kualitas produk dan keinginan untuk membeli produk berlabel standar. Hasil analisis cronbach alpha menemukan bahwa kuesioner penelitian ini telah reliabel. Dengan kata lain, kuesioner tersebut dianggap memiliki kemampuan untuk memberikan hasil pengukuran yang konsisten untuk variabel persepsi kualitas produk dan keinginan untuk membeli produk berlabel standar. Lebih lanjut, hasil uji reliabilitas menemukan bahwa nilai cronbaha alpha setiap variabel sudah berada diatas 0,7 . Hasil analisis cronbach alpha penelitian ini dapat dilihat pada tabel 4.

Tabel 4. Hasil Uji Reliabilitas Kuesioner

\begin{tabular}{lc}
\hline \multicolumn{1}{c}{ Variabel } & Cronbach Alpha \\
\hline Kualitas produk & 0,905 \\
Keinginan untuk membeli produk & 0,899 \\
\hline
\end{tabular}

\section{Uji Hipotesis}

\section{Uji Hipotesis Studi 1}

Secara umum, hasil analisis penelitian ini menemukan bahwa konsumen pria dan wanita tidak memiliki perbedaan signifikan dalam mengevaluasi produk berlabel standar, baik pada merek yang dikenal atau tidak dikenal. Lebih spesifik, tidak ada perbedaan persepsi kualitas produk antara pria dan wanita, baik pada produk kalkulator berlabel standar dengan merek Casio $\left(\mathrm{M}_{\text {pria }}=5,67, \mathrm{M}_{\text {wanita }}\right.$ $=5,56 ; \mathrm{t}=0,397$, Sig. $<0,05)$ atau Porpo $\left(\mathrm{M}_{\text {pria }}=4,38, \mathrm{M}_{\text {wanita }}=4,61 ; \mathrm{t}=0,930\right.$, Sig. $\left.<0,05\right)$, maupun produk detergen bubuk berlabel standar dengan merek Rinso $\left(\mathrm{M}_{\text {pria }}=5,20, \mathrm{M}_{\text {wanita }}=5,14\right.$; $\mathrm{t}=0,247$, Sig. $<0,05)$ atau Persil $\left(\mathrm{M}_{\text {pria }}=4,46 \mathrm{M}_{\text {wanita }}=4,36 ; \mathrm{t}=0,345\right.$, Sig. < 0,05). Disamping itu, hasil analisis juga menemukan bahwa pria dan wanita memiliki kesamaan dalam hal keinginan mereka untuk membeli kalkulator berlabel standar dengan merek Casio $\left(\mathrm{M}_{\text {pria }}=5,38, \mathrm{M}_{\text {wanita }}=5,40 ; \mathrm{t}\right.$ $=0,077$, Sig. < 0,05) atau Porpo $\left(\mathrm{M}_{\text {pria }}=4,13, \mathrm{M}_{\text {wanita }}=4,26 ; \mathrm{t}=0,443\right.$, Sig. $\left.<0,05\right)$, dan deterjen bubuk berlabel standar dengan merek Rinso $\left(\mathrm{M}_{\text {pria }}=4,76, \mathrm{M}_{\text {wanita }}=4,90 ; \mathrm{t}=0,438\right.$, Sig. $\left.<0,05\right)$ atau Persil $\left(\mathrm{M}_{\text {pria }}=4,26, \mathrm{M}_{\text {wanita }}=4,42 ; \mathrm{t}=0,512\right.$, Sig. < 0,05). Berdasarkan temuan tersebut, hipotesis $\mathrm{H} 1 \mathrm{a}$ dan $\mathrm{H} 1 \mathrm{~b}$ penelitian ini ditolak baik itu pada produk dengan merek dikenal atau tidak dikenal. Secara keseluruhan, hasil analisis perbedaan jenis kelamin dalam mengevaluasi produk berlabel standar dapat dilihat pada tabel 5. Lebih lanjut, nilai rata-rata pria dan wanita dalam mengevaluasi produk berlabel standar, baik pada produk sudah dikenal atau belum dikenal, dapat dilihat pada lampiran 1.

Tabel 5. Uji perbedaan jenis kelamin dalam mengevaluasi produk berlabel standar untuk konteks merek dikenal dan tidak dikenal

\begin{tabular}{lcccccc}
\hline $\begin{array}{l}\text { Variasi merek produk } \\
\text { berlabel standar }\end{array}$ & \multicolumn{2}{c}{ Persepsi kualitas produk } & \multicolumn{3}{c}{ Keinginan untuk membeli produk } \\
Rata-rata & $\mathrm{t}$ & Sig. & $\begin{array}{c}\text { Perbedaan } \\
\text { Rata-rata }\end{array}$ & $\mathrm{t}$ & Sig. \\
\hline $\begin{array}{l}\text { Merek dikenal } \\
\quad \text { Kalkulator (Casio) }\end{array}$ & 0,111 & 0,397 & 0,656 & 0,025 & 0,077 & 0,939 \\
$\quad \begin{array}{l}\text { Deterjen Bubuk } \\
\quad \text { (Rinso) }\end{array}$ & 0,061 & 0,247 & 0,806 & 0,147 & 0,438 & 0,664 \\
$\begin{array}{l}\text { Merek Tidak Dikenal } \\
\quad \text { Kalkulator (Porpo) }\end{array}$ & 0,224 & 0,930 & 0,365 & 0,147 & 0,443 & 0,661 \\
$\begin{array}{l}\text { Deterjen Bubuk } \\
\text { (Persil) }\end{array}$ & 0,099 & 0,345 & 0,740 & 0,164 & 0,512 & 0,612 \\
\hline
\end{tabular}




\section{Uji Hipotesis Studi 2}

Pada konteks tingkat keterlibatan produk, hasil analisis penelitian ini menemukan bahwa tidak ada perbedaan persepsi kualitas produk antara pria dan wanita, baik pada produk laptop berlabel standar $\left(M_{\text {pria }}=3,51, M_{\text {wanita }}=3,76 ; t=0,731\right.$, Sig. $\left.<0,05\right)$, smartphone berlabel standar $\left(M_{\text {pria }}=4,40\right.$, $\mathrm{M}_{\text {wanita }}=4,22 ; \mathrm{t}=1,168$, Sig. $\left.<0,05\right)$, dan senter berlabel standar $\left(\mathrm{M}_{\text {pria }}=3,87, \mathrm{M}_{\text {wanita }}=3,51 ; \mathrm{t}=\right.$ 0,615 , Sig. < 0,05). Disisi lain, untuk produk kipas angin berlabel standar, pria dan wanita memiliki perpedaan persepsi dalam menilai kualitas produk tersebut $\left(\mathrm{M}_{\text {pria }}=4,99 \mathrm{M}_{\text {wanita }}=4,29 ; \mathrm{t}=2,549\right.$, Sig. < 0,05). Disamping itu, hasil analisis juga menemukan bahwa pria dan wanita sama-sama memiliki keinginan untuk membeli produk berlabel standar, baik pada produk laptop $\left(\mathrm{M}_{\text {pria }}=3,16\right.$, $M_{\text {wanita }}=3,23 ; t=0,252$, Sig. $\left.<0,05\right)$, smartphone $\left(M_{\text {pria }}=4,26, M_{\text {wanita }}=4,11 ; t=0,322\right.$, Sig. $\left.<0,05\right)$, senter $\left(M_{\text {pria }}=3,30, M_{\text {wanita }}=3,19 ; t=0,526\right.$, Sig. $\left.<0,05\right)$, dan kipas angin $\left(M_{\text {pria }}=4,40, M_{\text {wanita }}=4,00\right.$; $\mathrm{t}=1,253$, Sig. $<0,05)$.

Tabel 6. Uji perbedaan jenis kelamin dalam mengevaluasi produk berdasarkan untuk konteks keterlibatan produk tinggi dan rendah

\begin{tabular}{lcccccc}
\hline \multicolumn{1}{c}{ Keterlibatan produk } & \multicolumn{2}{c}{ Persepsi kualitas produk } & \multicolumn{3}{c}{ Keinginan untuk membeli produk } \\
& $\begin{array}{c}\text { Perbedaan } \\
\text { Rata-rata }\end{array}$ & $\mathbf{t}$ & Sig. & $\begin{array}{c}\text { Perbedaan } \\
\text { Rata-rata }\end{array}$ & t & Sig. \\
\hline $\begin{array}{l}\text { Keterlibatan tinggi } \\
\quad \text { Laptop }\end{array}$ & 0,248 & 0,731 & 0,468 & 0,076 & 0,252 & 0,802 \\
$\quad \begin{array}{l}\text { Smartphone } \\
\text { Keterlibatan rendah }\end{array}$ & 0,357 & 1,168 & 0,247 & 0,105 & 0,322 & 0,749 \\
$\quad$ Senter & & & & & & \\
$\quad$ Kipas angin & 0,181 & 0,615 & 0,541 & 0,141 & 0,526 & 0,601 \\
\hline
\end{tabular}

Berdasarkan temuan tersebut, dapat dinyatakan bahwa sebagian besar tidak ada perbedaan jenis kelamin dalam mengevaluasi produk berlabel standar, baik pada produk dengan keterlibatan produk tinggi dan rendah. Dengan kata lain, hipotesis $\mathrm{H} 1 \mathrm{a}$ dan $\mathrm{H} 1 \mathrm{~b}$ penelitian ini ditolak untuk produk laptop, smartphone, dan senter. Sedangkan untuk produk kipas angin, Hipotesis H1a ditolak dan H1b diterima. Tabel 6 adalah hasil analisis perbedaan jenis kelamin dalam mengevaluasi produk berlabel standar berdasarkan keterlibatan produk. Lebih lanjut, nilai rata-rata pria dan wanita dalam mengevaluasi produk berlabel standar, baik pada produk dengan keterlibatan tinggi dan rendah, dapat dilihat pada lampiran 2.

\section{Pembahasan dan Implikasi}

Secara umum, hasil penelitian ini menemukan bahwa pria dan wanita memiliki kesamaan pandangan dalam mengevaluasi produk berlabel standar. Pada konteks pengenalan merek, penelitian ini menyatakan bahwa tidak ada perbedaan antara pria dan wanita dalam mengevaluasi produk berlabel standar, baik itu pada kualitas produk maupun keinginan untuk membeli suatu produk. Dengan kata lain, baik merek tersebut dikenal atau tidak dikenal, pria dan wanita memiliki kesamaan persepsi terhadap produk berlabel standar.

Disisi lain, pada konteks keterlibatan produk, hanya pada produk kipas angin, pria dan wanita memiliki perbedaan dalam mengevaluasi kualitas produk tersebut. Sisanya, seperti smarphone, laptop, dan senter, pria dan wanita memiliki kesamaan persepsi dalam mengevaluasi kualitas produk berlabel standar. Disamping itu, semua merek produk yang diuji pada penelitian ini juga menemukan bahwa pria dan wanita memiliki keinginan yang sama untuk membeli produk berlabel standar.

Penelitian ini telah menunjukan bahwa perbedaaan persepsi antara pria dan wanita dalam mengevaluasi produk berlabel standar bukan hanya disebabkan oleh faktor jenis kelamin saja, melainkan juga harus didukung oleh faktor lainnya. Pada penelitian ini, perbedaan persepsi antara 
pria dan wanita dapat terjadi ketika produk yang dievaluasi termasuk kategori produk dengan keterlibatan rendah. Faktor level keterlibatan produk tersebutlah yang dapat menyebabkan pria dan wanita memiliki perbedaan persepsi dalam menilai kualitas produk berlabel standar. Hal tersebut sejalan dengan teori elaboration likelihood model(Petty, Cacioppo dan Schumann,1983).

Berdasarkan temuan penelitian ini, penulis menyatakan bahwa pengaruh jenis kelamin dalam mengevaluasi produk berlabel standar tidak selalu berlaku pada semua jenis produk maupun merek. Bahkan, hasil penelitian ini menunjukan bahwa sebagain besar produk berlabel standar dipersepsikan sama oleh konsumen berjenis kelamin pria dan wanita. Dengan demikian, teori skema gender tidak selalu berlaku dalam proses pembelian produk berlabel standar. Lebih lanjut, tidak adanya perbedaan persepsi antara pria dan wanita dalam mengevaluasi produk berlabel standar pada penelitian ini telah memperkuat penelitan sebelumnya, yaitu Sebastianelli, Tamimi, dan Rajan (2008), Nguyen \& Gizaw (2014), serta Cela dan Cazacu (2016).

Tidak adanya perbedaan jenis kelamin dalam mengevaluasi produk berlabel standar dapat dijelaskan dengan teori hirarki kebutuhan maslow (Solomon, 2013). Teori tersebut menyebutkan bahwa setiap manusia, baik itu wanita atau pria, memiliki kebutuhan yang harus dipenuhi. Salah satu kebutuhan yang harus dipenuhi pria dan wanita adalah kebutuhan rasa keamanan. Dalam teori tersebut dijelaskan bahwa kebutuhan rasa aman muncul setelah kebutuhan dasar seseorang terpenuhi. Kebutuhan rasa aman adalah kebutuhan sesorang untuk mendapatkan rasa aman dalam kehidupannya, baik itu kebutuhan akan perlindungan atau kebutuhan terhindar dari rasa takut, bahaya, kerusuhan, bencana, penyakit, dan lainnya. Dalam konteks perilaku konsumen, kebutuhan rasa aman dapat dicerminkan dengan keinginan sesorang untuk mendapatkan produk yang berkualitas. Salah satu alasan konsumen membutuhkan produk yang berkualitas, karena produk yang berkualitas dipersepsikan konsumen sebagai produk yang dapat memberikan jaminan keamanan, keselamatan, kesehatan, kenyamanan, dan lainnya. Berdasarkan penjelasan teori hirarki kebutuhan maslow dapat dikatakan bahwa pria dan wanita sama-sama membutuhkan informasi terkait dengan jaminan kualitas. Lebih lanjut, pria dan wanita sama-sama membutuhkan produk dapat memberikan aspek keamanan, keselamatan, kesehatan, kenyamanan, dan lainnya. Dengan kata lain, mendapatkan produk yang berkualitas merupakan suatu keharusan, baik itu untuk pria atau wanita. Atas dasar kondisi tersebut, pria dan wanita sama-sama mencari informasi yang dapat memberikan jaminan tentang kualitas. Pada konteks penelitian ini, label standar dipandang sama pentingnya bagi konsumen pria dan wanita dalam proses keputusan pembelian produk.

Hasil penelitian ini telah memberikan implikasi manajerial. Implikasinya adalah para menajer yang ingin menggunakan label standar sebagai bagian penting dalam strategi komunikasi pemasaran tidak perlu membuat strategi khusus antara pasar sasaran (target market) berjenis kelamin pria dan wanita. Hal tersebut dikarenakan keberadaan label standar pada suatu produk dipandang sama pentingnya oleh konsumen pria maupun wanita. Dengan kata lain, keduanya memiliki preferensi yang sama terkait produk berlabel standar, bahwa produk berlabel standar adalah produk yang berkualitas dan mereka punya keinginan untuk membeli produk yang berlabel standar.

\section{Kesimpulan}

Salah satu label produk yang tidak boleh diabaikan oleh setiap produsen dalam mempromosikan produknya adalah label standar, karena dimata konsumen label standar memiliki hubungan yang erat dengan kualitas produk. Bahkan, banyak konsumen menjadikan label standar sebagai bahan pertimbangan utama dalam mengevaluasi suatu produk. Penelitian ini bertujuan untuk mengetahui ada atau tidak ada perbedaan antara pria dan wanita dalam mengevaluasi produk berlabel standar.

Kesimpulan penelitian ini menyatakan bahwa secara umum pria dan wanita memiliki kesamaan persepsi dalam mengevaluasi produk berlabel standar. Lebih spesifik, mereka memiliki persepsi yang sama terhadap kualitas produk berlabel standar, dan mereka juga memiliki keinginan yang sama untuk membeli produk berlabel standar. Meskipun begitu, hasil penelitian ini juga 
menunjukan bahwa dalam kondisi tertentu, pria dan wanita dapat memiliki perbedaan penilaian dalam mengevaluasi produk berlabel standar. Penelitian ini menunjukan bahwa pria dan wanita mungkin memiliki perbedaan persepsi kualitas produk, ketika produk yang dievaluasi termasuk dalam kategori produk dengan keterlibatan rendah.

Mengingat penelitian ini hanya dilakukan pada kalangan dengan umur berkisar 17-25 tahun, kesimpulan penelitian ini belum dapat digeneraliasai pada semua kalangan. Untuk dapat memberikan kontribusi penelitian secara luas, penelitian selanjutnya diharapkan dapat dilakukan pada golongan usia yang lain. Penelitian ini juga masih menggunakan pendekatan cross-sectional study, sehingga hasil penelitian ini memungkinkan memiliki hasil yang berbeda di waktu yang akan datang dalam jangka waktu yang panjang, karena adanya berbagai faktor lain dapat mempengaruhi cara berpikir konsumen pria dan wanita. Oleh karena itu, penelitian selanjutnya, peneliti dapat mengadopsi pendekatan longitudinal study untuk pengujian empris perbedaan jenis kelamin dalam mengevaluasi produk berlabel standar.

\section{Daftar Pustaka}

Bae, S dan Lee, T. 2011. Gender differences in consumers' perception of online consumer reviews, Electronic Commerce Research, 11, 201-214.

Bakti, IGMY. dan Sumaedi S. 2015. P-TRANSQUAL: a service quality model of public land transport services, International Journal of Quality \& Reliability Management, 32 (6), 534558.

Bem, S. L. 1981. Gender schema theory: A Cognitive account of sex typing. Psychological Review, 88 (4), 354-364.

Carpenter, M. dan Larceneux, F. 2008. Label equity and the effectiveness of values-based labels: an experiment with two French protected geographic indication labels. International Journal of Consumer Studies, 32, 499-507.

Caswell, Julie A. 2006. Quality assurance, information tracking, and consumer labeling. Marine Pollution Bulletin, 53, 650-656.

Cela, S. dan Cazacu S. 2016. The attitudes and purchase intentions towards private label products, in the context of economic crisis: a study of thessalonian consumers. ECOFORUM, 5, 124132.

Chao, Paul .2001. The Moderating Effects of Country of Assembly, Country of Parts, and Country of Design on Hybrid Product Evaluation. Journal of Advertising. 30(4), 67-81

Cooper, D. R. dan Schindler, Pamela S. 2008. Business Research Methods (10th edition), McGrawHill International Edition.

Delafrooz, N., dan Goli, A. 2015. The factors affecting the green brand equity of electronic products: Green marketing, Cogent Business \& Management, 2(1), 1-12.

Diamantopoulos, A., Sarstedt, M, Fuchs, C, Wilczynski, P., dan Kaiser, S. 2012. Guidelines for choosing between multi-item and single-item scales for construct measurement: a predictive validity perspective. Journal of the Academy of Marketing Science, 40 (3), 434-449.

Dimara, E. dan Skuras, D. 2005. Consumer demand for informative labeling of quality food and drink products: a European Union case study. Journal of Consumer Marketing, 22 (2), 90100.

Drichoutis, A.C., Lazaridis, P., dan Nayga, Jr. R.M. 2006. Consumers' use of nutritional labels: A review of research studies and issues. Academy of Marketing Science Review, 2006 (9), http://www.amsreview.org/articles/drichoutis09-2006.pdf. 
Fotopoulos, C., dan A. Krystallis. 2003. Quality labels as a marketing advantage: the case of the "PDO Zaragoza" apples in the Greek market. Europan Journal Marketing. 37(10), 13501374.

Guthrie, J.F., Jonathan, Fox, J.J., Cleveland, L.E., dan Welsh, S. 1995. Who uses nutrition labeling, and what effects does label use have on diet Quality ?. Journal of Nutrition Education, 27 (4), 163-172.

Ganesan-Lim, C., Russell-Bennett, R. dan Dagger, T. 2008. The Impact of Service Contact Type and Demographic Characteristics on Service Quality Perceptions. Journal of Services Marketing, 22(7), 550-561.

Hair, J.F., Anderson, R.E., Tatham, R.L., dan Black, W.C. 2006. Multivariate Data Analysis, 6th ed., Prentice Hall: New Jersey.

Huertas-Leyva, P., Quattelbaum, B., Solaz, J., dan Schmitt, R. 2011. Evaluation of perceived product quality for the integration in automotive industry supply chain, $13^{\text {th }} E A E C, 1-10$.

ISO .2015. ISO 9001, International Standard, Quality Management Systems Requirements, Geneva.

Kotler, P., dan Keller, K. L. 2012. Marketing management (14th ed.). Upper Saddle River, Prentice Hall: New Jersey.

Lassen, A.D., Lehmann, C., Andersen, E.W., Werther, M.N., Thorsen, A.V., Trolle, E., Gross, G., Tetens, I. 2011. Gender differences in purchase intentions and reasons for meal selection among fast food customers - Opportunities for healthier and more sustainable fast food. Food Quality and Preference, 47, 123-129.

Leclerc, F., Schmitt,B.H., dan Dube, L. 1994. Foreign Branding Its Effects on Product Perceptions and attitudes. Journal of Marketing Research. 31 (2), 263-270

Lumb, R. dan Lall, V. 2013. A Comparison of perceived product quality between Bulgarian and Chinese respondents. Innovative Marketing, 9 (1), 72 - 81.

Marakanon, L., dan Panjakajornsak, V. 2017, Perceived quality, perceived risk and customer trust affecting customer loyalty of environmentally friendly electronics products, Kasetsart Journal of Social Sciences, http://www.sciencedirect.com/science/article/pii/S2452315116301564

Mitra, D. dan Golder, P.N. 2006. How Does Objective quality Affect Perceived quality? Short-Term Effects, Long-TermEffects, and Asymmetries. Marketing Science, 25 (3), 230-247.

Mokhlis, Safiek. 2012. The Influence of Service Quality on Satisfaction: A Gender Comparison. The Influence of Service Quality on Satisfaction: A Gender Comparison, Public Administration Research, 1(1), 103-112.

Nayga, Rodolfo M. 1996. Determinants of consumers use of nutritional Information of food packages, Journal of Agricultural and Applied Economics, 28 (2), 303 - 312 .

Nayga, Rodolfo M. 2000. Nutrition knowledge, gender, and food label use, The Journal of Consumer Affairs, 34 (1), pp. 97-112.

Nguyen, T. dan Gizaw, A. 2014. Factors that influence consumer purchasing decisions of private label food products: a case study of ICA basic, School of Business, Society and Engineering, http://www.diva-portal.org/smash/get/diva2:705384/FULLTEXT01.pdf.

Park, H.-H., dan Sullivan, P. 2009. Market segmentation with respect to university students' clothing benefits sought: Shopping orientation, clothing attribute evaluation, and brand repatronage. International Journal of Retail \& Distribution Management, 37 (2), 182 - 201. 
Petty, R. E., Cacioppo, J. T., dan Schumann, D. 1983. Central and peripheral routes to advertising effectiveness: The moderating role of involvement. Journal of Consumer Research, 10 (2), 135-146

Rahmawati, T. 2016. Jenis Kelamin sebagai Variabel Moderasi dalam Hubungan Kualitas Pelayanan Pusat Kesehatan Masyarakat (Puskesmas) dan Kepercayaan Pasien: Sebuah Model Konseptual, Quality Management Review, 1 (1), 30-58.

Resano, H., Sanjuan, A.I. dan Albisu, L.M. 2007. Consumers' acceptability of cured ham in Spain and the influence of information. Food Quality and Preference, 18, 1064-1076.

Sampaio, P. Saraiva, P. dan Rodrigues, A.G. 2009. ISO 9001 certification research: questions, answers and approaches. International Journal of Quality \& Reliability Management, 26 (1), 38-58.

Sebastianelli, R., Tamimi, N. dan Rajan, M. 2008. Perceived Quality of Online Shopping: Does Gender Make a Difference?. Journal of Internet Commerce, 7(4), 445-469.

Solomon, Michael R. 2013. Consumer Behavior: Buying and Having $\left(10^{\text {th }}\right.$ edition), Pearson: Prentice Hall.

Srivastava, J., dan Mitra, A.1998. Warranty as a Signal of Quality: The Moderating Effect of Consumer Knowledge on Quality Evaluations. Marketing Letters, 9 (4), 327-336.

Tannock, J., dan Brown, H. 2006. Do consumers really care about ISO 9001 certification?. ISO Management Systems, (May - June), 21-26.

Torres, I.M., dan Briggs, E. 2007. Identification Effects on Advertising Response: The Moderating Role of Involvement, Journal of Advertising, 36 (3), 97-108.

van Dam, Y.K., dan van Trijp, HCM. 2006. Branding and labelling of food product, Understanding Consumers of Food Product, Woodhead Publishing Series in Food Science, Technology and Nutrition, 153-180.

Velčovska, Š., dan Marhounova M. 2005. Marketingovepojeti značky. VŠB-TU, Ostrava.

Velčovská, S. dan Sadílek, T. 2014. Analysis of Quality Labels Included in the European Union Quality Schemes. Czech J. Food Sci, 32(2). 194-203.

Verbeke, W., Pieniak, Z., Guerrero, L., dan Hersleth, M. 2012. Consumers' Awareness and Attitudinal Determinants of European Union Quality Label Use on Traditional Foods. Biobased and Applied Economics, 1(2), 213-229.

Wiley, J.B., Han, V., Albaum, G., dan Thirkell, P. 2009. Selecting techniques for use in an internet survey. Asia Pacific Journal of Marketing, 21 (4), 55-47.

Wee, C.S., Ariff, MSB., Zakuan, N., Tajudin, MNM. 2014. Consumers Perception, Purchase Intention and Actual Purchase Behavior of Organic Food Products, Review of Integrative Business dan Economics Research, 3(2), 378-397.

Yarmen, M., Rakhmawati, T., Bakti, IGMY., Astrini, N.J., Sumaedi, S., dan Widianti, T. .2016. Investigating Patient Loyalty: An Integrated Framework for Trust, Subjective Norm, Image, and Perceived Risk (A Case Study in Depok, Indonesia), International Journal of Quality and Service Sciences, 8 (2), 179-196.

Zhang, Y. dan Zinkhan G.M. 2006. Responses to Humorous Ads: Does Audience Involvement Matter?. Journal of Advertising, 35 (4), 113-127.

Zikmund, W.G, Babin, B.J., Carr, J.C. dan Griffin, M. 2008. Business Research Method 8th Edition, Cengage Learning : South-Western. 
Lampiran 1. Rata-rata pria dan wanita dalam mengevaluasi produk berlabel standar untuk konteks merek dikenal dan tidak dikenal

\section{Persepsi Kualitas Produk Berlabel Standar}

Kalkulator

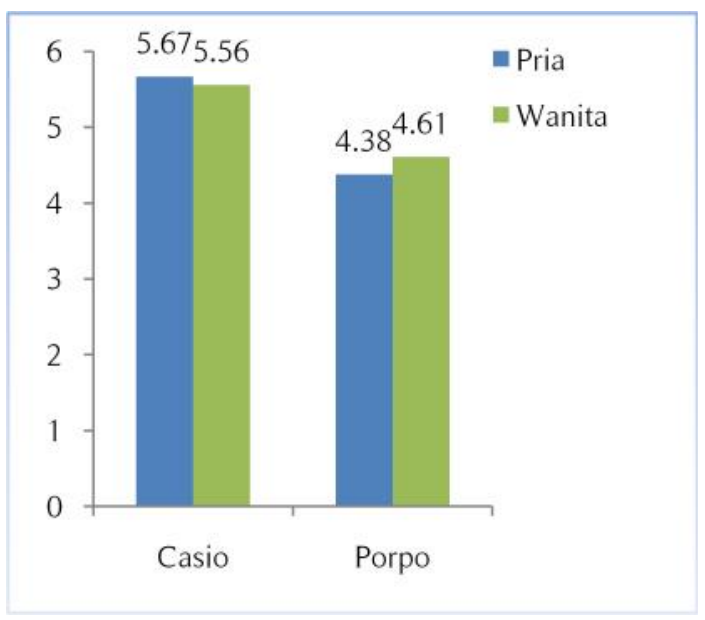

Deterjen Bubuk

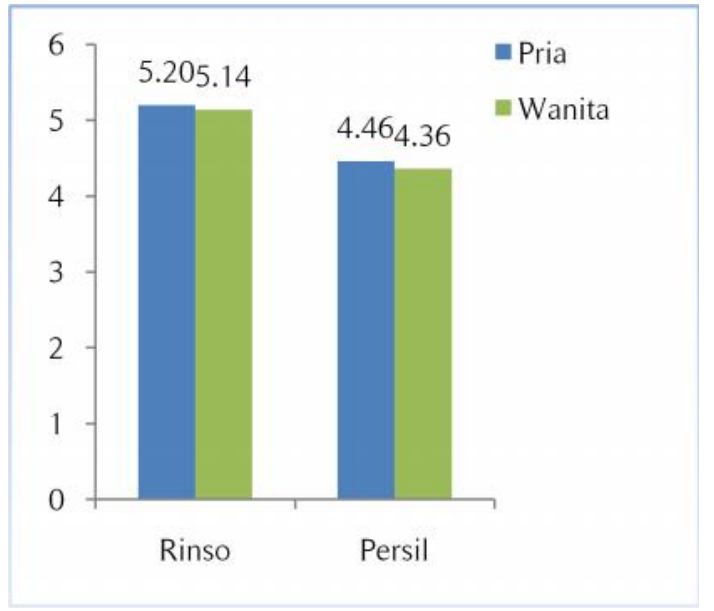

Niat Beli Produk Berlabel Standar

Kalkulator

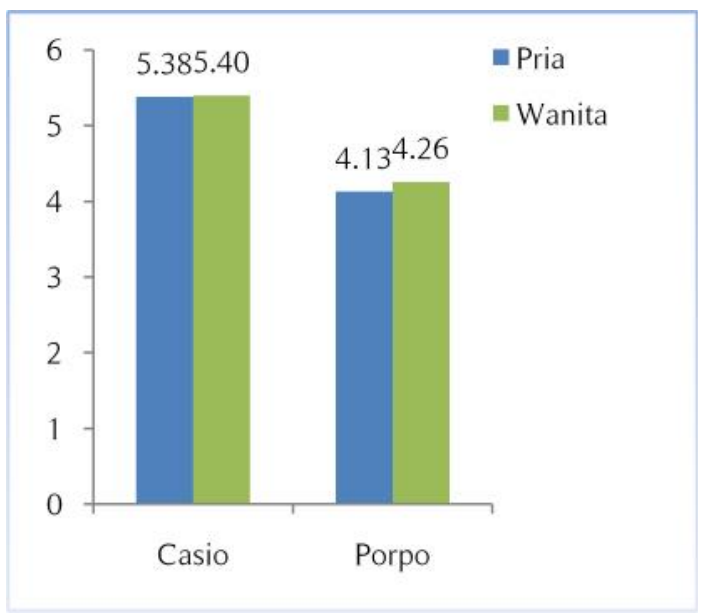

Deterjen Bubuk

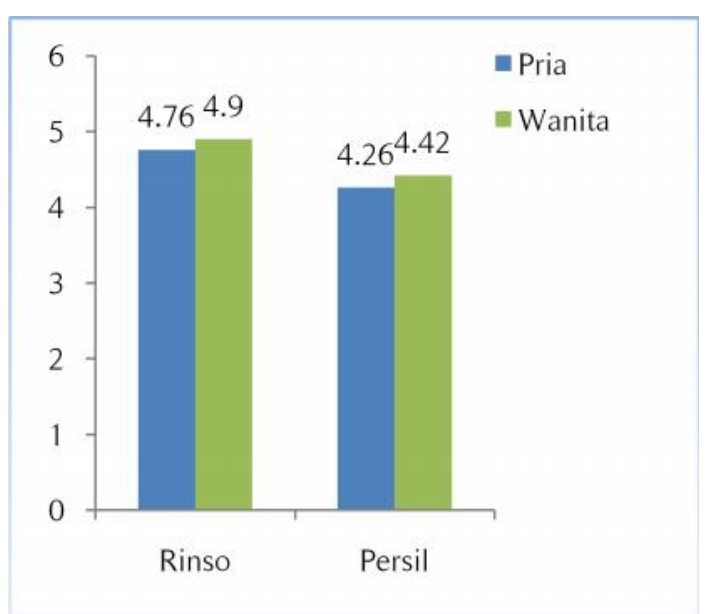


Lampiran 2. Rata-rata pria dan wanita dalam mengevaluasi produk berlabel standar untuk konteks keterlibatan produk tinggi dan rendah

\section{Persepsi Kualitas Produk Berlabel Standar}
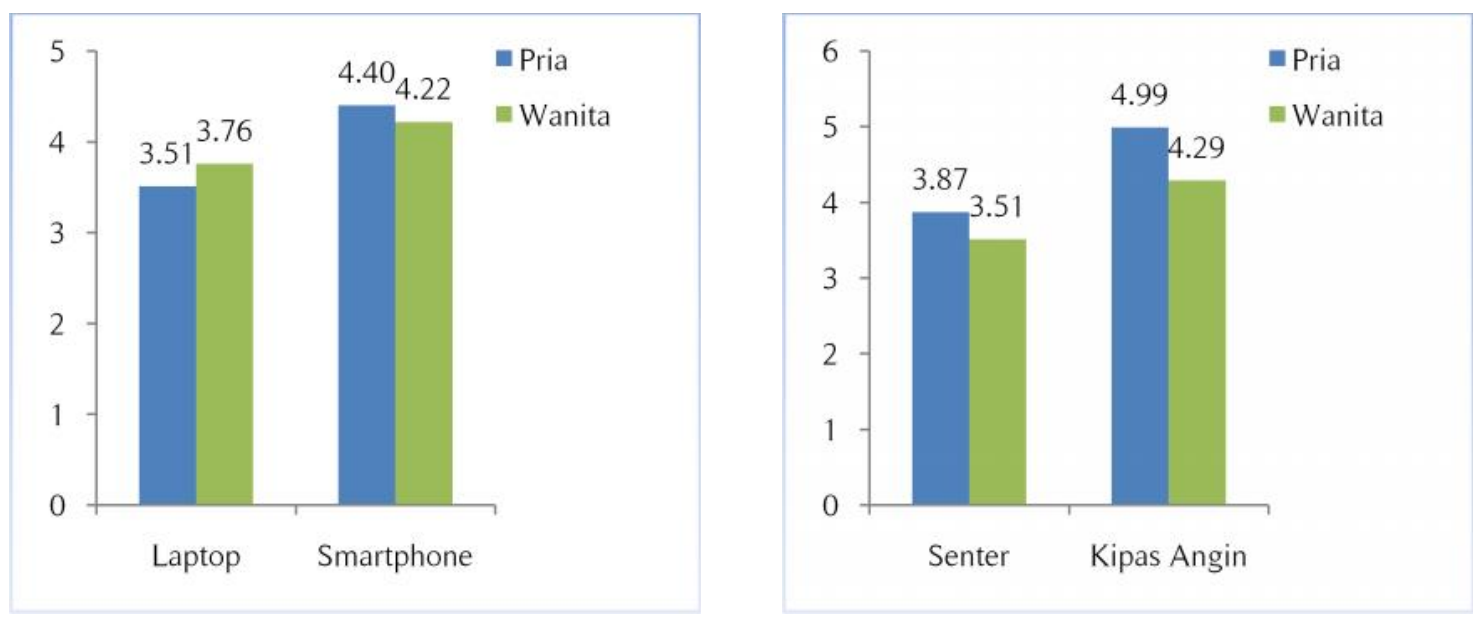

Niat Beli Produk Berlabel Standar
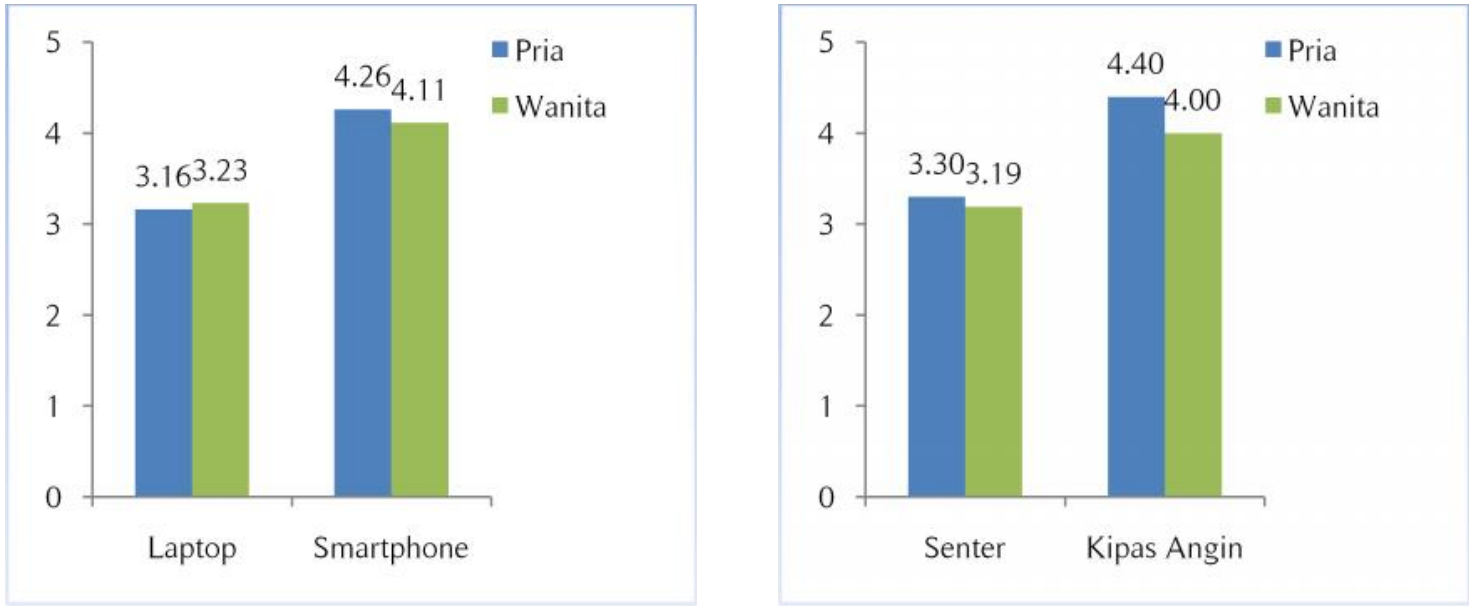